\begin{tabular}{ll}
\hline \hline MINING AND METALLURGY INSTITUTE BOR & ISSN: 2334-8836 \\
& UDK: 622 \\
\hline \hline
\end{tabular}

UDK: $622.36: 624.137(045)=20$

DOI:10.5937/MMEB1303065C

Salko Ćosić, Mevludin Avdić, Amir Sušic ${ }^{* *}$, Milenko Ljubojev ${ }^{* * *}$

\title{
FINITE ELEMENT ANALYSIS OF DEEP UNDERGROUND SALT CAVERNS ${ }^{* * * *}$
}

\begin{abstract}
In this paper, the process of finite element analysis of deep underground salt caverns was described with geometry and material properties related to caverns in the salt mine Tetima-Tuzla, B\&H. The 3D model was built based on ultrasound measurement and CAD modelling of planar geometry data. Nonlinear finite element analysis was performed resulting in stresses and deformations data necessary for assessment of cavern stability and time dependent behaviour.
\end{abstract}

Keywords: finite element analysis, CAD model, stress and deformation fields, plasticity and creep

\section{INTRODUCTION}

Besides the many advantages, there are also some drawbacks related to leaching exploitation of deep underground salt caverns. Leaching process leads to enlargements of caverns and subsequently to reducing of its stability. Due to high lithostatic pressure at cavern depth, failure of cavern walls is possible if its dimensions are above certain limit. In order to maintain stability, it is necessary to stop leaching process when cavern reaches some critical dimensions. Exploited cavern must be filled with water and sealed. The leaching process has to be continued at new cavern(s) usually in the vicinity of previous one. The position, dimensions and leaching dynamics of the new cavern is influenced with other caverns in the vicinity. There are protective pillars between caverns that are necessary to maintain the stability of caverns. The pillars are highly loaded with internal (litho-static) pressure at cavern depth. The calculation of geometrical disposition of caverns and its critical diameters is a complex task. Up to now, some recommendations were usually used on the basis of elasticity theory models and empirical data from previous years of exploitation. The theory of elasticity allows stress-strain calculation in the case of ideal, homogeneous, isotropic, linearly elastic material and cylindrical, spherical or elliptical shape of caverns. Unfortunately, in the real-world conditions, the rock salt deposit are layered with nonhomogeneous layers, the rock materials are anisotropic; the constitutive behaviour is nonlinear and inelastic. Also, the cavern shape is usually far away from the ideal, cylindrical or spherical case for which analytical models can be useful. Therefore, the analytical models, based on elasticity theory, have limited usefulness in the practical stress state calculations. It is

\footnotetext{
* University of Tuzla, Bosnia and Herzegovina

** d.d. Rudnik soli Tetima, Tuzla, Bosnia and Herzegovina

*** Mining and Metallurgy InstituteBor, Serbia

**** This paper was written under the Project No.36014, funded by the Ministry of Education, Science and Technological Development of the Republic of Serbia for the period 2011 - 2014.
} 


\section{THE FEM MODEL OF SALT CAVERNS}

therefore, necessary to have larger coefficients of safety related to the critical caverns diameters and its mutual axial distance. It leads to stopping of leaching before it is really necessary at the moment when cavern is fully formed and gave its maximum production and transfer to a new cavern with small size and small capacity. Also, the axial distance between caverns must be larger, that means, lot of salt material is permanently lost.

High improvement in this field came with the finite element analysis. It allows nonlinear analysis of stress-strain state with advanced material models and realistic geometry (shape) of caverns and layers of rock materials. The result is more reliable prediction of caverns behaviour and its mutual interactions. Such analysis with geometrical and material parameters, related to the rock salt mine "Tetima" in the vicinity of Tuzla, Bosnia and Herzegovina, is given in this work.
The first step in FEM analysis is development of CAD model with realistic caverns geometry and positions in salt deposit. The stress-strain state will be analyzed for the group of five caverns and pillars between them, situated at the Tetima mine, near Tuzla, Bosnia and Herzegovina. The actual geometry of cavern walls is obtained by ultrasonic measurement. The ultrasonic measuring head is down warded, from the surface to the bottom of cavern, taking series of flat scans (2D) in the plane normal to cavern axis, shown in Figure 1. Contour lines are modeled as splines allowing smooth cavern surface and solid model to be generated by 3D modelling software. Caverns are between 80 and 100 meters high and with diameters up to 40 meters. All caverns are situated at 500-700 meters from the surface. The volume of one entirely developed cavern is approximately $100,000 \mathrm{~m}^{3}$.

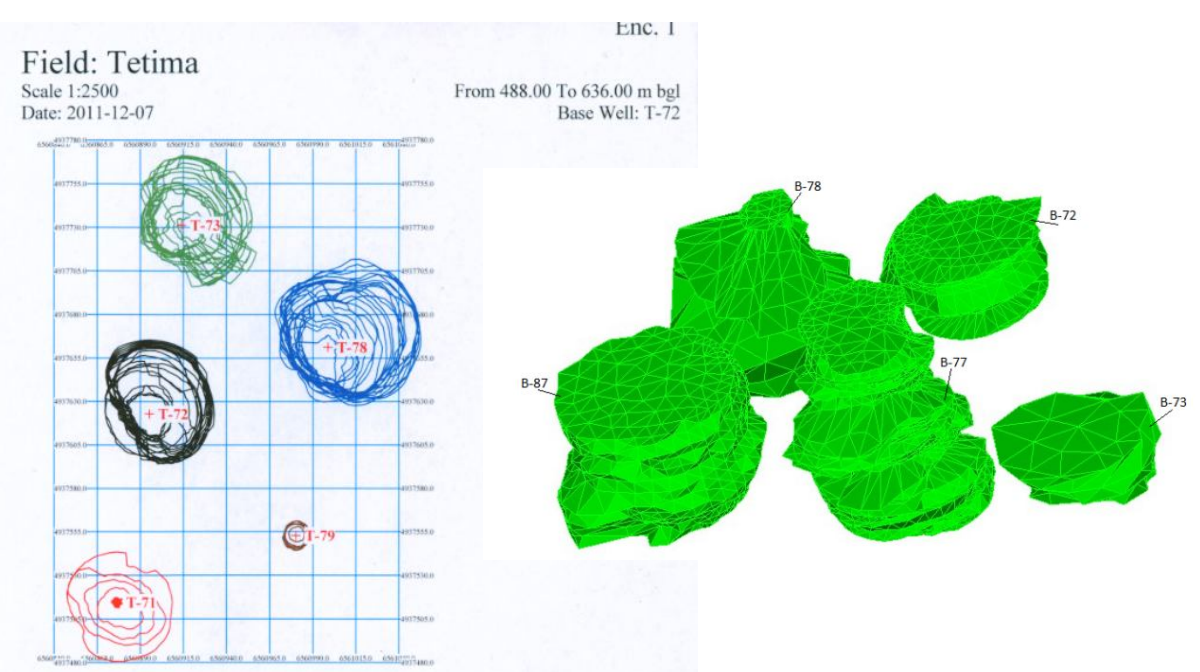

Figure 1 Caverns cross-sections by ultrasonic measurements(a) and appropriate $3 D$ solid models $(b)$ 
3D solid model of individual caverns is shown in Figure1 (b). Caverns are obtained by subtraction of previously generated 3D solids from layered deposit model (Figure 2.a). Model dimensions are $300 \times 200$ x 600 $\mathrm{m}$. It is adequate to include all five caverns and to exclude influence of the rest of salt deposit. In order to reduce model height (depth 500-700 m) at upper surface, a uniformly distributed external pressure equivalent to litho-static pressure at appropriate depth is applied. It leads to significant reduction of DOF in FEM analysis with minor reduction of accuracy. All layers are modelled based on geophysical measurements and geological maps.
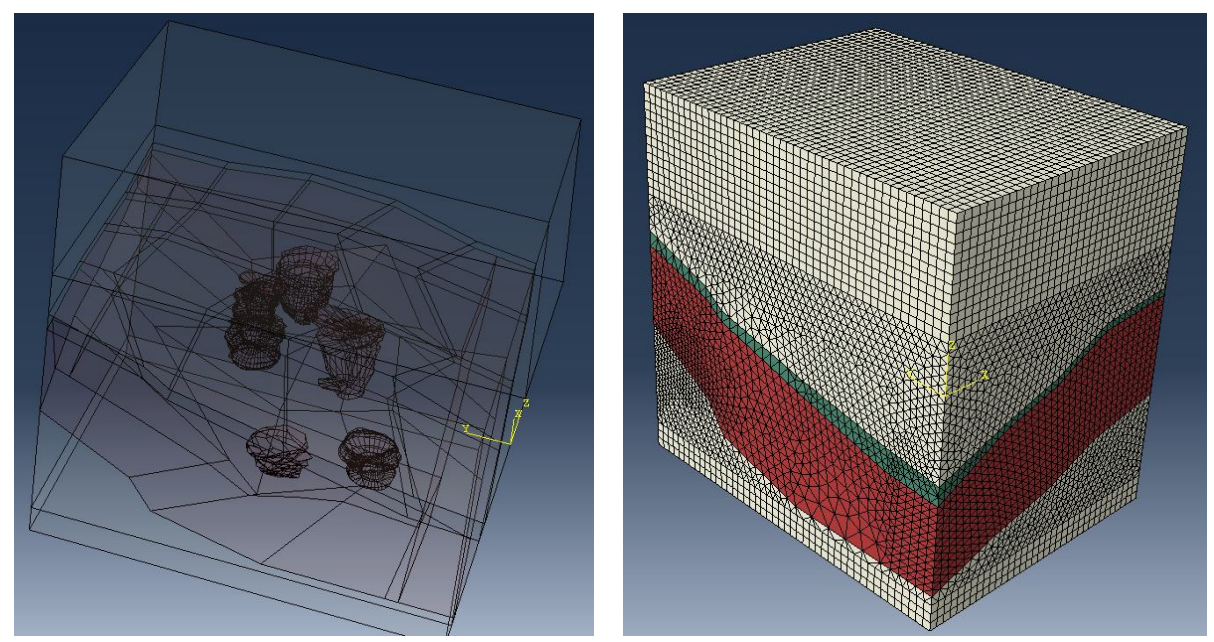

Figure $23 D$ layered CAD model of caverns and its disposition in the Tetima mine(a), discretized domain (b)

\section{PREPROCESSING}

\subsection{Model Partitioning and Mesh Generation}

Before discretization on finite elements, it is necessary to do domain partitioning in order to allow better mesh generation. The complicated curved parts of domain (salt cavern walls) are discretized on standard linear tetrahedral elements but large part of domain is discretized on more advanced hexahedral elements, Figure 2. In this way, there is a compromise between the mesh quality, number of degrees of freedom in problem and hardware (computing) capacity of our computers. Total number of degrees of freedom for entire model is around 380,000. After defining caverns geometry and automatic mesh generation, the material model, loads, boundary conditions and interface between cavern and surrounding material are defined.

\subsection{Material Modelling}

In the real conditions, the domain is layered with many different rock materials. The base material (rock salt) under 


\subsection{Boundary Conditions}

high pressure has the elasto visco-plastic behaviour. Therefore, the FEM analysis is nonlinear, time dependent, with many increments of loads and many iterations steps. The parameters for material model are determined by fitting the experimental measurement results on many salt samples, according to the standardised procedures. Another rock material is modeled as linearly elastic by the Drucker-Pragger plasticity model. In the space of principal stresses, the D-P model is given as (1) and salt creep model is given by (2):

$$
\begin{aligned}
& \sqrt{J_{2}}=a+b \cdot I_{1} \text { ili } \\
& \sqrt{\frac{1}{6}}\left[\left(\sigma_{1}-\sigma_{2}\right)^{2}+\left(\sigma_{1}-\sigma_{3}\right)^{2}+\left(\sigma_{2}-\sigma_{3}\right)^{2}=\right. \\
&= a+b \cdot\left(\sigma_{1}+\sigma_{2}+\sigma_{3}\right) \\
& \overline{\varepsilon_{c r}}=\left(A \cdot \sigma^{n}\left[(m+1) \overline{\varepsilon_{c r}}\right]^{m}\right)^{\frac{1}{m+1}}
\end{aligned}
$$

The constants (material parameters) a, $\mathrm{b}, \mathrm{A}, \mathrm{n}$ and $\mathrm{m}$ in equations (1) and (2) are found experimentally.
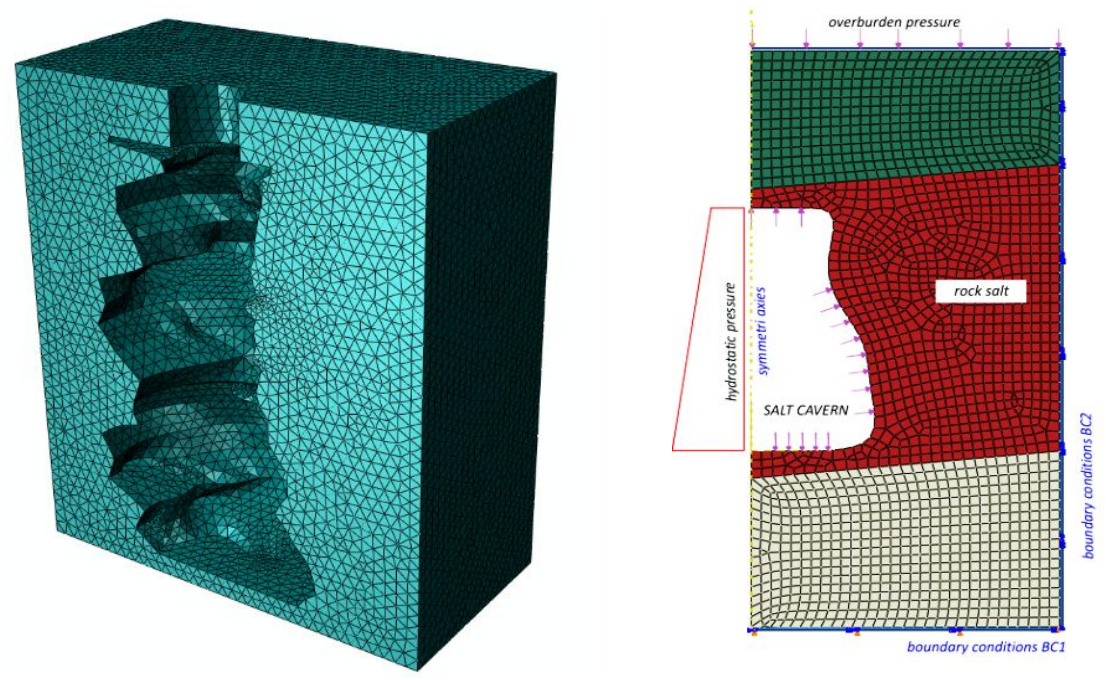

Figure 3 Discretized cavern model (a), standard boundary conditions (b) 


\section{DISCUSION OF RESULTS}

Resulting system of equations in discrete form were solved in approximately $200 \mathrm{~min}$. of PC time. Due to intense plastic deformation of several elements, the analysis was performed in several increments of load (30) and approximately 5-6 iteration steps in every increment. The most interesting result variables are displacement field, during leaching process and after. The magnitude of displacement field is shown in Figure 4. Maximum vertical displacement is about 1.3 $\mathrm{m}$. and it is located at free surface above cavern no. 73. Due to visco-plastic behaviour of rock salt, it is assumed that vertical displacements shall rise in cavern surrounding with time. Vertical displacements in another cross section are much smaller. Also, the effect of rising of bottom for all caverns can be seen. It is easy to explain, because the internal pressure at cavern bottom is hydrostatic, $\mathrm{p}=\rho_{\text {watergh }}$, but the external pressure is much higher, equal to $\mathrm{p}=\rho_{\text {rock }} \mathrm{gh}$.

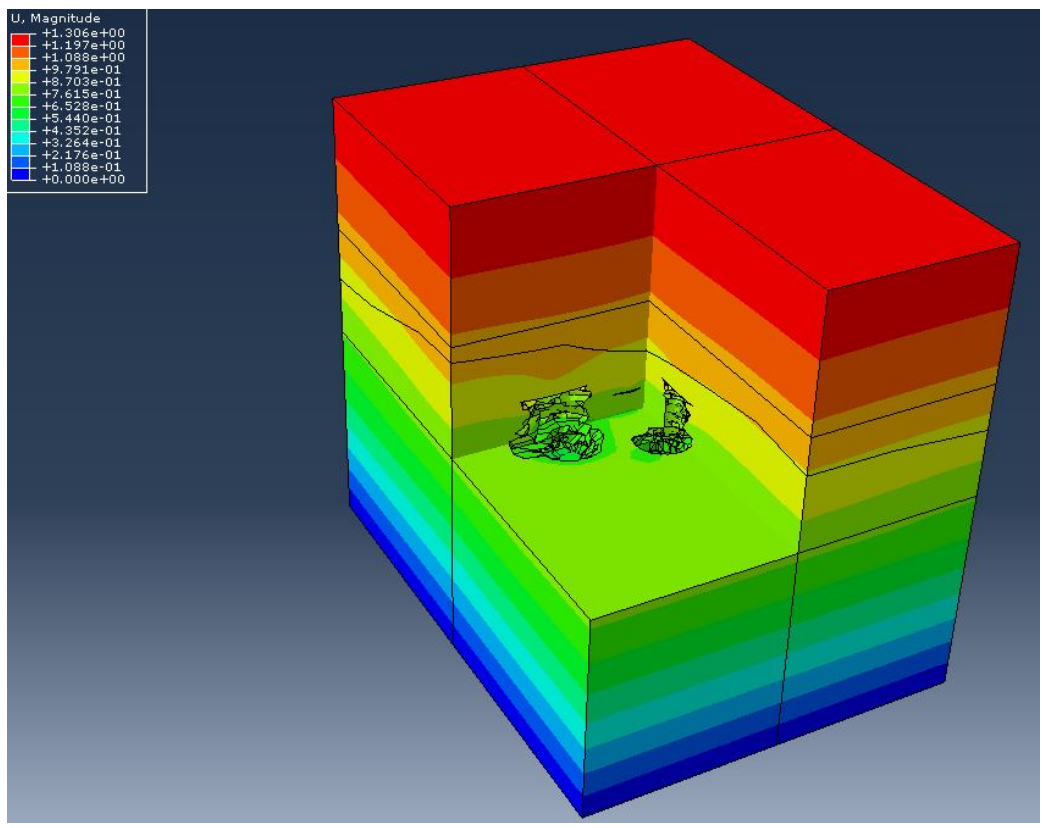

Figure 4 Magnitude of displacements in cavern cross section

In Figure 5, We can see displacements distribution in horizontal cross section $\left(\mathrm{u}_{2}\right)$. High pressure outside of cavern and lower pressure inside, and reduced horizontal stiffness due to caverns (cavity in material) leads to horizontal displacements of magnitude $\pm 210^{-2} \mathrm{~m}$. In a case when internal hydrostatic pressure is re duced to zero (empty caverns), the stress equilibrium is lost due to non-symmetric shape of cavern and it leads to collapse of cavern walls. In the simulation process, this is related with loss of convergence. Layered material and uneven distribution of pillar thickness between caverns also contribute to this effect. 


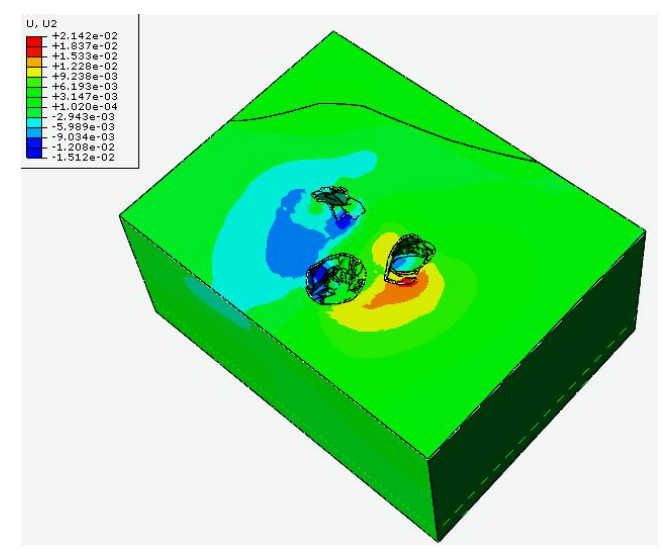

Figure 5 Distribution of horizontal displacement, $u_{2}$

For stress analysis, the most important is the effective stress related to the DruckerPraggerplasticity criterion. The nodal point's effective stress can be compared with uniaxial stresses leading to the plastic deformation, obtained experimentally at rock samples. The analysis shows stresses higher the $20 \mathrm{MPa}$ that are beyond the layered materials yield stresses. The most severe stress concentrations are at sharp corners in cavern walls, but number of such situations is relatively small with respect to the cavern dimensions. Also, such places are disjoined, far away one from another. In the real conditions, the geometry changes and sharp corners are not so severe, it can be assumed that plastic deformations will remain loca-lised and corresponding plastic zones will be separated. Also, the local plastic deformation will lead to decreasing of stress gradients in the local zone. In whole model, for given geometrical and material parameters, any larger plastic zone was not found, only small, disconnected local plastic zones.

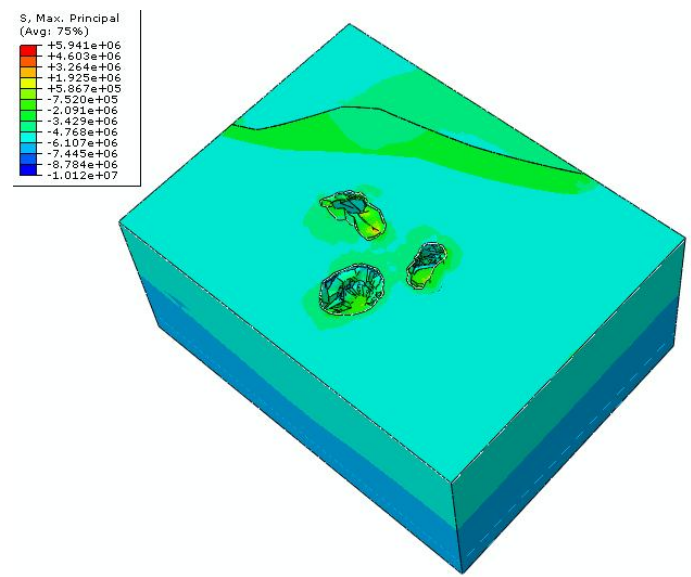

Figure 6 First principal stress distribution $\left(\sigma_{P I}\right)$ 
As rock materials have reduced strength with respect to the extension stress, distribution of the first principal stress, $\sigma_{\mathrm{p} 1}$ is shown in Figure 6. It shows maximum extension stress in every nodal point. Checking many cross sections of a model in three perpendicular planes, it is realized that extension stresses $\sigma_{\mathrm{p} 1}$ are relatively small, except in already mentioned areas with high stress concentrations. In such points, the plastic deformations occur, leading to equalisation and decreasing of extension stresses. The high magnitude of another principal stresses that are compressive $\left(\sigma_{\mathrm{p} 1}\right.$ and $\left.\sigma_{\mathrm{p} 1}\right)$ improves the global model stability.

\section{CONCLUSIONS}

The general conclusion obtained by described nonlinear finite element analysis is that the model is in stabile elastic state, with localised stress concentrations and correspondding plastic deformation at sharp corners in cavern walls. There is no any larger plastic zone and horizontal displa-cements are relatively small. The tangential stresses are little bit larger in pillars between caverns, but there is no severe plastic deformation there. The stresses in the upper protective plate have caused local plastic deformations at several places, but it is still in stabile state. In the first layer above the salt, the local potential possibility has cracks due to low ultimate extension stress for that material. The material parameters of rock materials are highly scattered, so the average values are used in numerical analysis. With such material parameters, there is no any indicator of global cavern instability or global instability of pillars between caverns. The zones with plastic deformations are strictly localised and separated. Visco-plastic effect will lead to spreading of plastic zones, but also to stress reduction and equalisation of its distribution. The cavern volume will decrease with time. Maximum value of vertical displacement includes displacement due to the historical terrain subsidence and excavation by leaching. Magnitude of the last one is approximately $0.3 \mathrm{~m}$ at depth of $200 \mathrm{~m}$ from free surface. It is relatively small related to the cavern dimensions. So, the main conclusion is that the cavern group is still in stabile state, but many local plastic zones indicate that it can reach its ultimate dimensions. Therefore, it is compulsory to watch surface settling, to have regular ultrasound measurements of caverns geometry and to perform subsequent nonlinear finite element analysis.

\section{REFERENCES}

[1] Bobet A.: „Numerical Methods in Geomechanics", The Arabian Journal for Science and Engineering, Volume 35, Number 1B, 2010

[2] Dowling, N. E., "Mechanical Behavior of Materials. Engineering Methods for Deformation, Fracture, and Fatigue" Second Editon, 1999.

[3] F. Kočar: The Rheological Properties of Rock Salt from Tuzla Basin, Bosnia and Herzegovina, FMGC Tuzla, 1971 (in Bosnian)

[4] Hartmut von Trayller, LorencoMusso: „Controlled Cavern Leaching in Bedded Salt Without Blanket in Timpa del Salto" Spring 2006 Conference, Brussels, Belgium

[5] Jeremic M. L.: "Rock mechanics in salt mining", Springer ISBN-10: 9054101032, 1994

[6] K. L. De Vries, K. D. Mellegard, G. D. Callahan, W. M. Goodman: "Cavern Roof Stability for Natural Gas Storage in Bedded Salt, Topical Report RSI1829 DE-FG26-02NT41651, prepared for the United States Department of Energy, Mill Road Pittsburgh, Pennsylvania June 2005

[7] Minkley W., Menzel W.: "A Viscoelasto-plastic Softening Model and its 
Application for Solving Static and Dynamic Stability Problems in Potash Mining", Institut für Gebirgsmechanik $\mathrm{GmbH}$, Leipzig, Germany

[8] Munson, D. E.; Devries, K. L., "Development and Validation of a Predictive Technology for Creep Closure of Underground Rooms in Salt" Seventh International Congress on Rock Mechanics. Vol 1, pp 127134, Aachen/Deutschland, 1991.

[9] Munson, D. E. Analysis of Multistage and Other Creep Data for Domal Salts, SAND98-2276, Sandia National Laboratories, Albuquerque, NM, January 1998.
[10] Otossen N. S.: "Viscoelastic-Viscoplastic Formulas for Analysis of Cavities in Rock Salt, Int. J. Rock Mech. Min. Sci and Geomech, Vol 23, No3, pp 201-212, 1986

[11] Steven R. Sobolik, Brian L. Ehgartner: "3D Cavern Enlargement Analysis" Sandia National Laboratories Report SAND2001-0526, Albuquerque, USA, April 2000

[12] G. Hadži-Nikovic, S. Ćorić, J. Gomilanović, Application of 3D Slope Stability Analysis in Defining the Excavation Conditions of Coal at the Open Pits, Mining and Metallurgy Engineering Bor 2/2013, p. 1-10 


\begin{tabular}{ll}
\hline \hline INSTITUT ZA RUDARSTVO I METALURGIJU BOR & ISSN: 2334-8836 \\
& UDK: 622 \\
\hline \hline
\end{tabular}

\title{
NAPONSKO-DEFORMACIONA ANALIZA SONIH KOMORA METODOM KONAČNIH ELEMENATA ${ }^{* * * *}$
}

\begin{abstract}
Izvod
U ovom radu opisujemo proces naponsko-deformacione analize dubokih sonih komora metodom konačnih elemenata. Geometrijske $i$ geomehaničke osobine komora i stijenskih slojeva odgovaraju istima na rudniku soli "Tetima" u Tuzli, BiH. 3D model je izrađen na osnovu serije ravnih ultrazvučnih snimaka duž ose svake komore. Izvođenjem nelinearne MKE analize došlo se do naponsko-deformacionog stanja masiva u zoni eksploatacije,neophodnog za procjenu stabilnosti i ponašanja komora.

Ključne reči: MKE analiza, CAD model, sona komora, distribucija napona i deformacija
\end{abstract}

\section{UVOD}

Eksploatacija ležišta kamene soli metodom izluživanja osim prednosti vezana je i za niz poteškoća. Širenje podzemnih komora (kaverni) velikih dimenzija u ležištu soli vezano je za povećanje opasnosti od gubitka stabilnosti komore. Kolaps izaziva litostatički pritisak kome je komora na velikoj dubini izložena. U cilju održanja stabilnosti tj. izbjegavanja kolapsa neophodno je zaustaviti ekspolataciju kada se veličina komore približi kritičnoj granici, istu hermetički zatvoriti i preći na izluživanje nove, susjedne komore. Položaj i dinamika izluživanja nove komore takođe imaju veliki uticaj na već zatvorenu komoru. Potrebno je osigurati da zaštitni stubovi od kamene soli između komora mogu nositi visoke vrijednosti spoljnih (litoloških) pritisaka na dubini komore. Određivanje potrebnih geometriskih parametara (prečnici komora i rastojanja između osa istih) je složen zadatak. U dosadašnjim istraži- vanjima i praksi uglavnom su se koristili ili empirjski ili obrasci teorije elastičnosti. Ovi drugi omogućavaju da se za homogen, izotropan, linearno elastičan materijal odredi naponsko stanje pri postojanju cilindričnih, eliptičnih ili sferičnih šupljina i njihovih kombinacija pri odgovarajućim graničnim uslovima [11]. Na žalost, u realnim uslovima, ležište kamene soli je daleko od homogenog, izotropnog, linearno-elastičnog materijala. Ono je najčešće slojevito, sa različitim, nehomogenim slojevima, stijenski materijal (kamena so, mineral halit) je u opštem slučaju anizotropan i njegova konstitutivna relacija je nelinearna $i$ neelastična. Takođe, oblik (geometrija) stvarne komore bitno odstupa od cilindričnog ili sferičnog oblika za koji su razvijeni analitički modeli. Jasno je da prethodno spomenuti analitički modeli mogu dati samo približnu sliku naponskog stanja te da se zbog složenosti i nepouzdanosti mora raditi

\footnotetext{
* Univerzitet u Tuzli, Bosna i Hercegovina

** d.d.Rudnik soli Tetima, Tuzla, Bosna i Hercegovina

**** Institut za rudarstvo i metalurgiju Bor

**** Ovaj rad je realizovan u okviru projekta broj 36014 koji se finansira od strane Ministarstva prosvete, nauke i tehnološkog razvoja Republike Srbije, za period 2011 - 2014.
} 
sa većim stepenima sigurnosti. Ovo se u praktičnom smislu ogleda kroz zatvaranje komore (prestanak eksploatacije) možda i znatno prije nego što je to zaista neophodno, u fazi kada ista ima najveću produktivnost, prelazak na novu komoru koja u početnoj fazi izluživanja zbog malih dimenzija ima i vrlo malu produktivnost kao i ostavljanje znatno većeg zaštitnog stuba između stare i nove komore čime je taj mineralni materijal trajno izgubljen. Pojava FEM metode analize napona i deformacija dovela je do bitnog napretka $\mathrm{u}$ ovom području. Ista omogućava nelinearnu analizu napona i deformacija u zoni komore sa naprednijim modelima materijala i realističnom geometrijom koja uzima u obzir slojevitost materijala i stvarni oblik komore. Time se omogućava pouzdanija procjena stanja i ponašanja pojedinačne komore kao i međusobne interakcije više komora $u$ ležištu. Proceduru takve analize na primjeru komora rudnika „Tetima“ u Tuzli dajemo u nastavku rada.

\section{MKE MODEL SONIH KOMORA}

Početna faza FEM analize podrazumijeva izradu realističnog CAD modela ležišta sa komorama. U nastavku će mo prikazati naponsko-deformacionu analizu zaštitnih stubova između više (5) komora na rudniku „Tetima“ u Tuzli, Bosna i Hercegovina. Geometrija stvarnih komora utvrđena je ultrazvučnim snimanjem. Sonda se spušta po osi komore sa površine do dna i daje niz ravnih (2D) ultrazvučnih snimaka, u ravni normalnoj na osu komore, sl. 1 (a). Konturni presjeci se opisuju spline funkcijama koje se koriste za generisanje 3D solida. Komore su orjentaciono 80-100 m. visoke, prečnika do $40 \mathrm{~m}$ i na dubini od 500700 m. Zapremina jedne komore orijentaciono iznosi $100.000 \mathrm{~m}^{3}$.

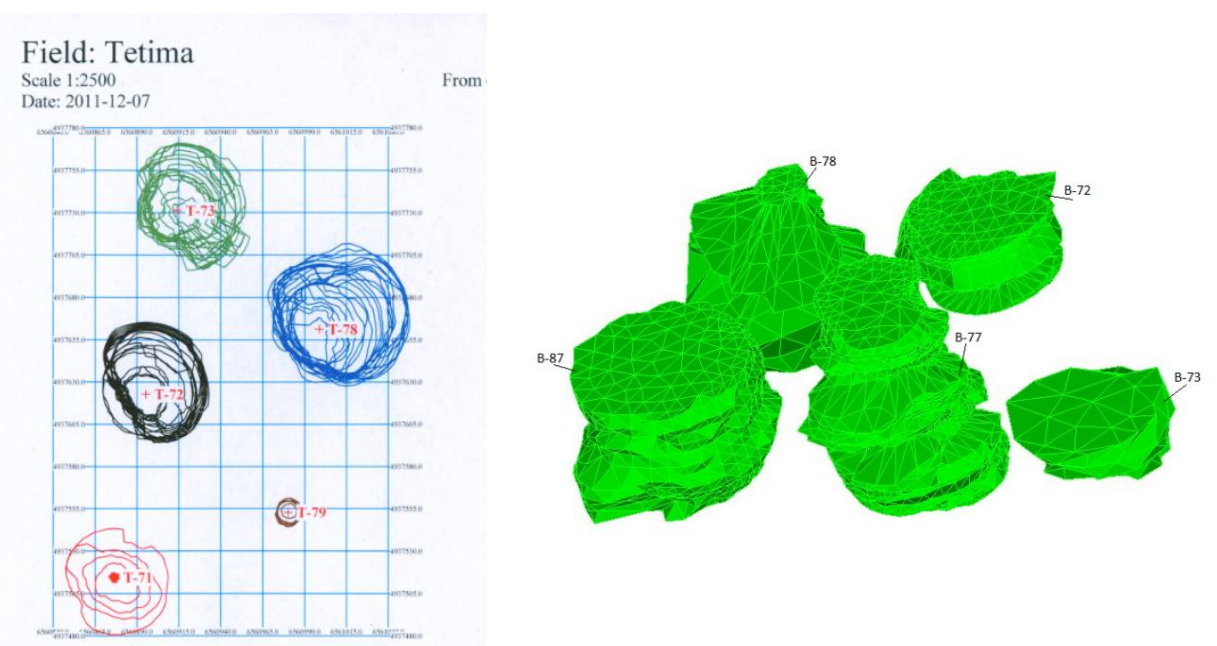

Sl. 1. Ultrazvučni snimak, presjek na odgovarajućoj visini komore (a), 3D solid modeli (b)

3D solidmodel pojedinačne komore prikazan je na slici 2 (a). CAD model obuhvata 5 komora koje su modelirane na osnovu serije ultrazvučnih snimaka. Komore (šupljine) su dobijene "oduzimanjem" 3D modela punih komora od prethodno pri- premljenog modela sloja kamene soli, sl. 2 (b). Dimenzije modela ( $300 \times 200 \times 600) \mathrm{m}$. su takve da se obuhvate sve komore od interesa te da se bočni uticaji ostatka masiva svode na standardne što podrazumijeva da se fiksiraju pomaci svih tačaka u pravcu 
normale na površinu. S obzirom na dubinu na kojoj se nalazi gornja površina komora, da bi se smanjila veličina modela, izostavlja se stijenski materijal (sloj laporca), a njegov uticaj se kompenzira dodavanjem ravno-
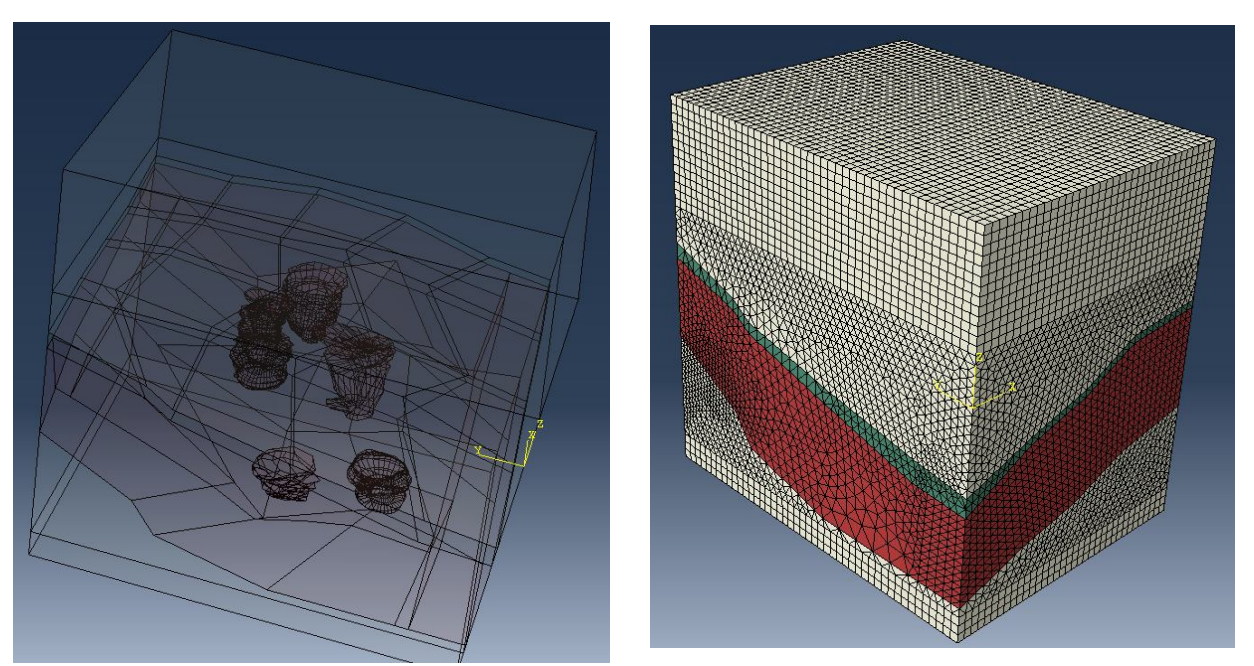

Sl. 2. 3D slojeviti CAD model komora u ležištu rudnika „Tetima“ (a), diskretizirana domena (b)

\section{PRE-PROCESIRANJE}

\subsection{Generisanje MKE mreže}

Prije diskretizacije na konačne elemente je izvršeno je particioniranje modela kako bi se omogućila izrada naprednije heksagonalne mreže elemenata tamo gdje je to moguće. Zakrivljeni dijelovi komore sa složenom geometrijom modeliraju se pomoću standardnih linearnih tetraedarskih elemenata. Na ovaj način (particioniranjem) postignut je kompromis između broja elemenata (broj stepeni slobode) u modelu, kvaliteta aproksimacije i računske mogućnosti hardvera na kome se obavlja FEM analiza. Na sl. 2 (b) prikazan je diskretizirani model. Ukupan broj stepeni slobode modela iznosi oko 380.000 .

Nakon definisanja geometrije modela, preprocesiranje obuhvata automatsko generisanje mreže, definisanje modela mate- mjerno raspoređenog pritiska po litostatičkom zakonu po gornjoj površini modela. Slojevi (litološki članovi) su modelirani na osnovu raspoloživih geoloških podataka i karata. 
elastični sa Drucker-Pragger-ovim uslovom tečenja $\mathrm{u}$ oblasti plastičnosti. U prosturu glavnih napona, Drucker-Prager uslov loma dat je sa (1) dok je efekt puzanja modeliran sa (2):

$$
\begin{aligned}
& \sqrt{J_{2}}=a+b \cdot I_{1} \text { ili } \\
& \sqrt{\frac{1}{6}}\left[\left(\sigma_{1}-\sigma_{2}\right)^{2}+\left(\sigma_{1}-\sigma_{3}\right)^{2}+\left(\sigma_{2}-\sigma_{3}\right)^{2}=\right. \\
& =a+b \cdot\left(\sigma_{1}+\sigma_{2}+\sigma_{3}\right) \\
& \overline{\varepsilon_{c r}}=\left(A \cdot \sigma^{n}\left[(m+1) \overline{\varepsilon_{c r}}\right]^{m}\right)^{\frac{1}{m+1}}
\end{aligned}
$$

Konstante a, b, A, n i m u (1) i (2) su određene eksperimentalno.

\subsection{Granični uslovi}

Dimenzije modela su izabrane dovoljno velike tako da se na stranama mogu primijeniti standardni geomehanički granični uslovi prikazani na sl. 3 (b) za slučaj 2D analize. Za površinu koja odgovara donjoj bazi modela je usvojeno da je vertikalni pomak jednak nuli. Za bočne površine modela je usvojeno da su pomaci u pravcu normalom na bočne ravni jednaki nuli. Time je model pravilno i dovoljno fiksiran $u$ prostoru.

\subsection{Opterećenje}

Opterećenje potiče od sopstvene težine i zadaje se preko faktora gravitacije i gustoće materijala. Na gornju površinu dodat je eksterni pritisak koji kompenzira odgovarajuću visinu stijenskog masiva od gornje plohe modela do slobodne površine. Veličina eksternog pritiska jednaka je pritisku na dubini od $180 \mathrm{~m}$ pri gustoći materijala od $2100 \mathrm{~kg} / \mathrm{m}^{3}$. Pritisak u unutrašnosti komora se mijenja linearno sa dubinom i jednak je vrijednosti hidrostatičkog pritiska na odgovarajućoj dubini, $\mathrm{p}=\rho \mathrm{gh}$.
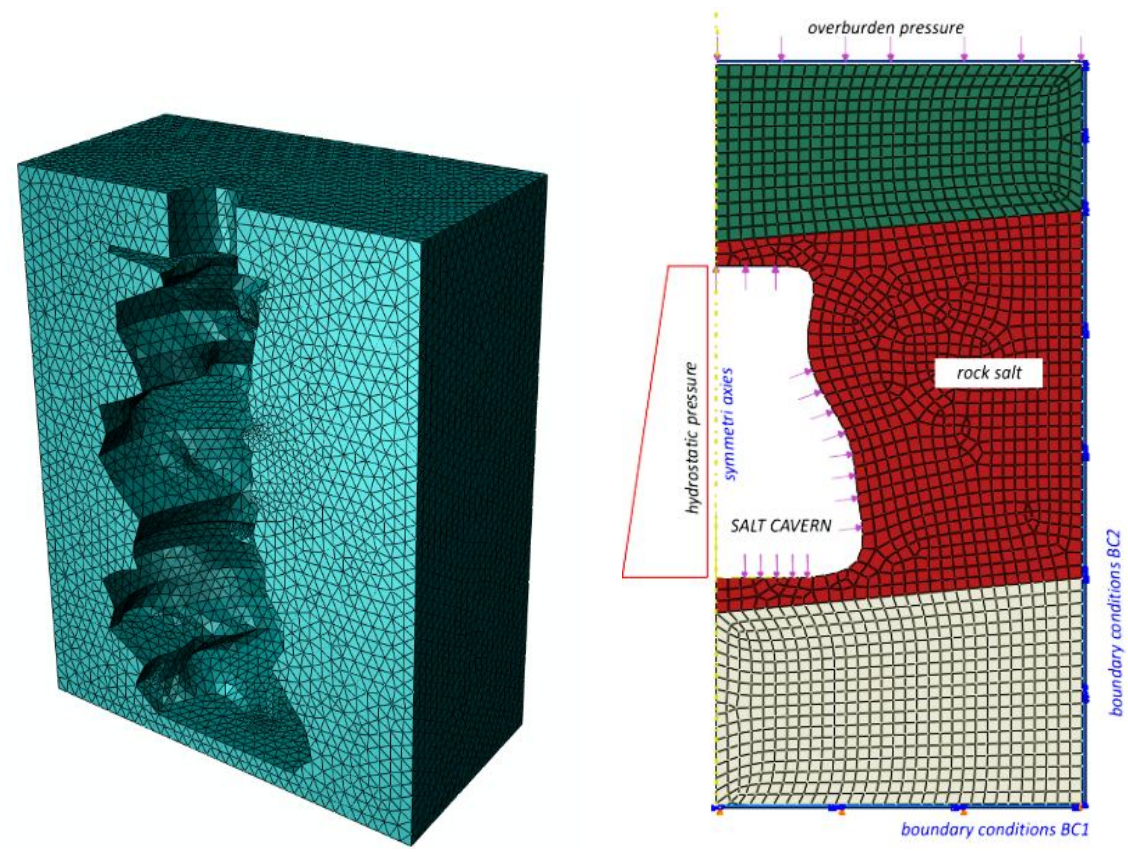

Sl. 3. Diskretizirani MKE model komore (a), standardni granični uslovi (b) 


\section{ANALIZA REZULTATA}

Rezultujući diskretni sistem (nelinearnih) jednačina se rješava za cca 200 minuta rada PC računara. Zbog izrazito lokalizovanog plasticifiranja nekoliko elemenata, analiza se vrši u više inkremenata opterećenja (max. 30) sa 2-6 iteracija po inkrementu. U praktičnom smislu, od interesa su polja pomaka koji nastaju u toku i nakon eksploatacije. Distribucija magnitude pomaka za date parametre prikazan je na sl. 4 . Maksimalno utvrđeno vertikalno pomjeranje iznosi oko $1.306 \mathrm{~m}$ i locirano je na površini u zoni projekcije komore br. 73. S obzirom na visko-elasto-plastične efekte koje pokazuje ruda soli, očekuje se blagi porast vertikalnog pomaka s vremenom, u čitavoj zoni. Vertikalni pomaci u ostalim presjecima su bitno manji. Uočljivo je i podizanje dna komore što je sasvim razumljivo s obzirom na znatno više vrijednost pritiska u masivu soli izvan nego u slanoj vodi unutar komore.

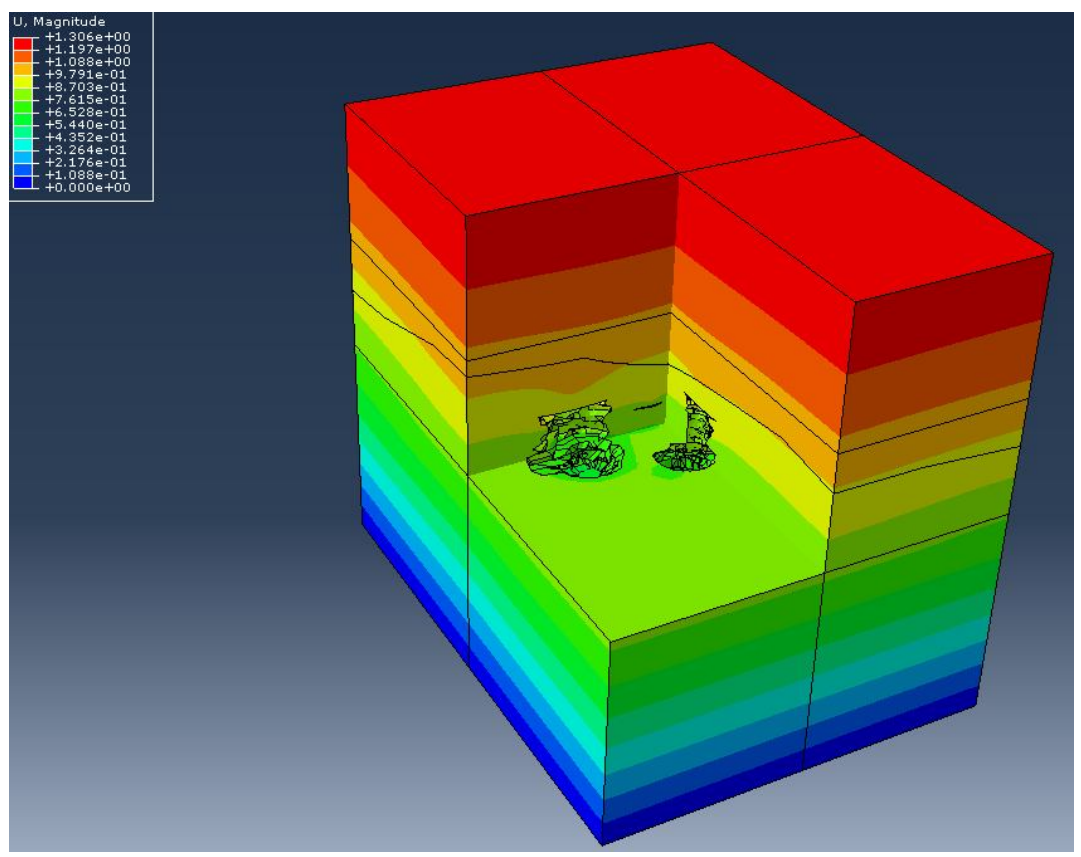

SI. 4. Magnituda pomaka u poprečnom presjeku

Na sl. 5 prikazano je polje horizontalnog pomjeranja $\left(\mathrm{u}_{2}\right) \mathrm{u}$ horizontalnom presjeku kroz komore. Visoke vrijednosti pritisaka unutar i izvan komora te smanjena krutost materijala u horizontalnoj ravni uslijed postojanja šupljina dovode do bočnih pomaka reda veličine od $-2 \mathrm{do}+2 \mathrm{~cm}$. U slučaju da se neutrališe unutrašnji hidro- statički pritisak (prazna komora) bočni pomaci postaju bitno veći i dovode do kolapsa komore (u numeričkom smislu gubi se konvergencija nakon velikog broja iteracija). Tome doprinose i neravnomjerno raspoređeni bočni pritisci koji nastaju uslijed neravnomjerne debljine i mehaničkih osobina materijala slojeva. 


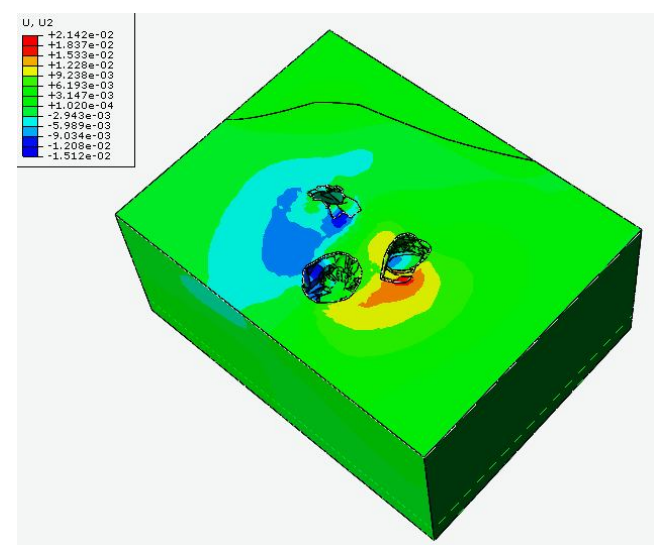

S1. 5. Distribucija horizontalnog pomaka

Za analizu napona najmjerodavniji je efektivni napon koji se $\mathrm{u}$ ovom slučaju računa prema Drucker-Prager kriteriju plastičnog tečenja. Izračunate vrijednosti napona u čvornim tačkama (skalarne veličine) pružaju mogućnost poređenja sa eksperimentalno utvrđenim jednoosnim naponima koji dovode do plastične deformacije. Analizom su utvrđeni naponi reda veličine $20 \mathrm{MPa}$ koji prekoračuju granice tečenja materijala slojeva. Najveći naponi se javljaju na izolovanim mjestima na površini komora u presjecima koji imaju nagle i oštre promjene geometrije. Broj takvih mjesta je relativno mali $\mathrm{i}$ ista su udaljena jedno od drugoga. U stvarnim uslovima, promjena geometrije nije tako izrazita i konture nisu tako „oštre” kao što je to prikazano na modelu, tako da se smatra da se ovdje radi o lokalnim plastičnim deformacijama. Plastična deformacija tih elementa će dovesti do ravnomjernije distribucije napona i rasterćenja tih presjeka. U modelu, za zadate parametre materijala i opterećenja, nije utvrđena pojava nastanka i širenja plastificirane zone većih dimenzija.

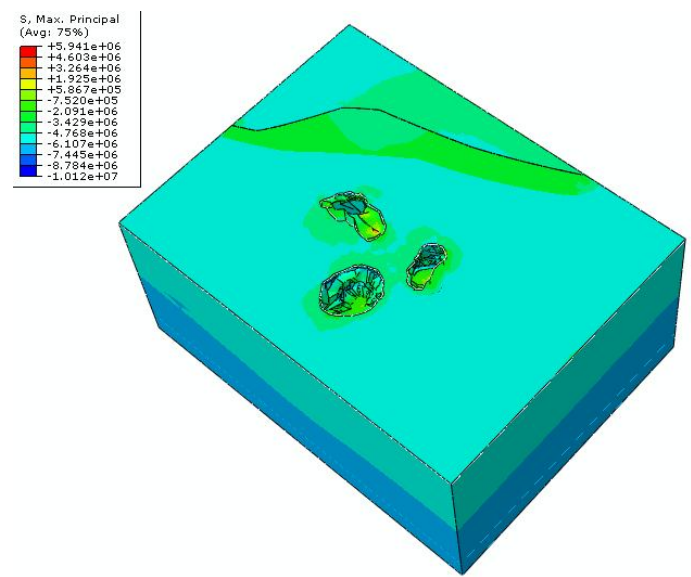

Sl. 6. Prvi glavni napon ( $s P 1)$ 
Budući da stijenski materijali ne podnose istezanje, na slici 6. je prikazana distribucija maksimalnog glavnog napona. Analizom distribucije ovog napona sa promjenom položaja presjeka modela utvrđeno je da isti ima relativno malu vrijednost $u$ čitavom modelu osim u nekoliko kritičnih tačaka koje se nalaze na mjestima nagle promjene geometrije komore (oštre ivice ili uglovi). U takvim tačkama dolazi do lokalne plastične deformacije čime se naponi istezanja smanjuju i uravnotežavaju sa okolinom. Visoka vrijednost druga dva glavna napona (kompresivni) povoljno djeluje na stabilnost komore tako da osim lokalnih plastičnih deformacija u blizini oštrih uglova ili ivica, $u$ cjelini model se nalazi u elastičnom stanju sa umjerenim vrijednostima napona i deformacija.

\section{ZAKLJUČAK}

Generalni zaključak dobijen analizom pomaka kroz čitav model je da nema intenzivnih pomjeranja $\mathrm{u}$ zoni komora. Tangencijalni naponi koji su i najveći uzročnik pojave plastičnih deformacija pokazuju nešto veću vrijednost $u$ dijelu materijala između komora što je i razumljivo obzirom na već spomenuto kod analize pomaka. Analizom naponsko - deformacijskog stanja u području predviđene zone zaštitne ploče uočavaju se pojave plastičnih deformacija, ali njihov intenzitet nije $u$ toj mjeri izražen da bi dao pokazatelj eventualnog proloma zaštitnog stuba. Rezultati naponske analize i plastičnih deformacija za materijal iznad soli ukazuju na tačke potencijalne zone pojave pukotina i narušavanja homogenosti sloja. U proračunu su uzete srednje dobijene vrijednosti geomehaničkih parametara. Podaci dobijeni ovom analizom ukazuju da nema pokazatelja o spajanju komora i narušavanju postojećih međukomornih stubova. Utvrđene plastične deformacije su male magnitude i obuhvataju mala područja. Visko-plastični efekat koji ispoljava so će dovesti do širenja ovog područja ali sa opadanjem napona i povećanjem ravnomjernosti distribucije. Dobijena veličina maksimalnog vertikalnog pomaka, a koja je navedena u radu sadrži pored uticaja slijeganja terena usljed eksploatacije i "istorijsku" vrijednost pomaka koji je bio prije početka eksploatacije. Ako se uzme u obzir i ovaj parametar onda se ta vrijednost kreće u granicama do 0.3 metra na dubini od 200 metara od površine. Opšti je zaključak da je naponsko stanje stabilno, naponi u glavnini materijala su još uvijek u elasticčnom području ali i da je blizu granica plastificiranja i velikih deformacija jer su neka najnepovoljnija područja već zahvaćena istom.

\section{LITERATURA}

[1] A. Bobet: „Numerical Methods in Geomechanics“, The Arabian Journal for Science and Engineering, Volume 35, Number 1B, 2010

[2] N. E. Dowling, "Mechanical Behavior of Materials. Engineering Methods for Deformation, Fracture, and Fatigue" Second Editon, 1999.

[3] F. Kočar, Reološke osobine kamene soli Tuzlanskog basena, RGGF Tuzla, 1971 (in Bosnien)

[4] H. von Trayller, L. Musso, ,Controlled Cavern Leaching in Bedded Salt Without Blanket in Timpa del Salto“ Spring 2006 Conference, Brussels, Belgium

[5] M. L. Jeremic: "Rock mechanics in salt mining", Springer ISBN-10: 9054101032, 1994

[6] K. L. De Vries, K. D. Mellegard, G. D. Callahan, W. M. Goodman: "Cavern Roof Stability for Natural Gas Storage in Bedded Salt", Topical Report RSI1829 DE-FG26-02NT41651, prepared for United States Department of Energy, Mill Road Pittsburgh, Pennsylvania, June 2005. 
[7] W. Minkley, W. Menzel, "A Viscoelasto-plastic Softening Model and its Application for Solving Static and Dynamic Stability Problems in Potash Mining", Institut für Gebirgsmechanik $\mathrm{GmbH}$, Leipzig, Germany

[8] D. E. Munson, K. L. Devries, "Development and Validation of a Predictive Technology for Creep Closure of Underground Rooms in Salt" Seventh International Congress on Rock Mechanics. Vol 1, pp 127-134, Aachen/Deutschland, 1991.

[9] D. E. Munson, Analysis of Multistage and Other Creep Data for Domal Salts SAND98-2276, Sandia National Laboratories, Albuquerque, NM, January 1998.
[10] N. S. Otossen, "Viscoelastic-Viscoplastic Formulas for Analysis of Cavities in Rock Salt, Int. J. Rock Mech. Min. Sci and Geomech, Vol 23, No3, pp 201-212, 1986

[11] S. R. Sobolik, B. L. Ehgartner: "3D Cavern Enlargement Analysis" Sandia National Laboratories Report SAND2001-0526, Albuquerque, USA, April 2000.

[12] G. Hadži-Niković, S. Ćorić, J. Gomilanović, Primena 3D analize stabilnosti kosina pri definisanju uslova iskopa uglja u površinskim kopovima, Mining and Metallurgy Engineering Bor 2/2013, str. 11-20 